Original Article

\title{
ASSESSMENT OF BIOLOGY ACTIVITY OF THE PEELING SUBSTANCES BY THE PHYSICOCHEMICAL APPROACHES ON THE SPIROSTOMUM AMBIGUUM CELL MODEL
}

\author{
USPENSKAYA E. V., ${ }^{*}$ PLETENEVA T. V., PHAM MY HANH, KAZIMOVA I. V. \\ Peoples Friendship University of Russia (RUDN University), Department of Pharmaceutical and Toxicological Chemistry, 6, Miklukho- \\ Maklaya St, Moscow, 117198, Russian Federation \\ *Email: uspenskaya75@mail.ru
}

Received: 28 Apr 2021, Revised and Accepted: 01 Jun 2021

ABSTRACT

Objective: To evaluate the biological activity of chemical peeling substances based on enzymatic and Arrhenius kinetics using Spirostomum ambiguum as an alternative approach to animal experiments.

Methods: The Spirotox method was used to analyze the mechanism of «xenobiotic-cell» interaction, similar to the Michaelis-Menten enzymatic kinetics. The Hill-Langmuir equation was used to determine the degree of cooperativity in the binding of xenobiotics to cellular receptors. Using the Arrhenius kinetics, the observed activation energy obsEa of cell death in the model solutions of glycolic and carbolic acids was determed, which will allow predicting the toxicity parameters of any peeling substances.

Results: The relationship Spirostomum ambiguum lifetime $t_{L} \cdot \lg C$ concentration of peeling compound solution made it possible to characterize the moment of cellular transition from the intermediate state $C \cdot L_{n}$ to the dead state $D C$, characterized by irreversible structural and functional changes in the cell/death. The values were $5.3 \mathrm{mmol}^{-1} \mathbf{l}^{-1}$ for glycolic acid solutions and $2.8 \mathrm{mmol} \cdot \mathbf{l}^{-1}$ for carbolic acid solutions. Equilibrium constants $K_{\text {eq }}$ of complexation, the rate of infusoria death $f_{m}$, and the degree of ligand cooperativity $n$ were calculated. The activation energy ${ }^{\circ b s} E_{a}$ of cell death was determined in Arrhenius coordinates, which were $210 \pm 0.39 \mathrm{~kJ} \cdot \mathrm{mol}^{-1}$ and $108 \pm 0.09 \mathrm{~kJ} \cdot \mathrm{mol}^{-1}$ for glycolic and carbolic acids respectively. The correlation between the values of activation energy and $D L_{50}$ of mammals (rats) was discovered.

Conclusion: The obtained kinetic parameters made it possible, without animals and humans testing, to characterize the mechanisms of interaction of peeling substances with the living cell.

Keywords: Peeling, Glycolic acid, Phenol, Spirotox method, Biological activity, Animal-free test

(C) 2021 The Authors. Published by Innovare Academic Sciences Pvt Ltd. This is an open access article under the CC BY license (https://creativecommons.org/licenses/by/4.0/) DOI: https://dx.doi.org/10.22159/ijpps.2021v13i7.41927. Journal homepage: https://innovareacademics.in/journals/index.php/ijpps.

\section{INTRODUCTION}

Chemical peeling (chemexfoliation) stimulates the appearance of controlled keratocoagulation and denaturing proteins in the epidermis and dermis, the release of pro-inflammatory cytokines and chemokines, and the production of new skin collagen and elastin [1-5]. The clinical effectiveness of chemical peeling, as well as the risk of various complications, depends on many factors: the properties of chemicals, concentration, regimen, and the number of uses, skin type, dermatological condition, and cumulative dose [6, 7]. Despite available reviews about the traumatic nature of this procedure, chemical peeling ranks third in the frequency of non-invasive cosmetic procedures in the USA [8]. Since the use of cosmetic products is not associated with an urgent need for the life and health of consumers, there is the number of advocates of alternative in vitro approaches to animal experiments, for example, when checking the safety of cosmetics [914]. Cosmetic animal testing is banned in a few countries [15]. For the testing of cosmetics, programs are being developed to enable the cosmetics industry to conduct safety assessments $[16,17]$. To date, testing methods without the use of animals have been selected, including cell lines [18].

Alternative models use various cellular cultures, specialized moving cells, bacteria, single-celled organisms, primitive crustaceans and other hydrobionts. Methods based on the reactions of the simplest animals are of paramount importance in today's environment, as they allow determining the possible range of properties in a short period the substance under study and making recommendations on whether to investigate it further. For example, there are approaches to describing the kinetics of the development of cellular population under the influence of inhibitors and promoters [19]. It is also important that biological research methods using protozoa significantly reduce the time required to study the properties of substances and are characterized by a relatively low cost. Replacing warm-blooded animals with unicellular ones reduces the time of toxicological and pharmaceutical studies from one year to a month, and the cost of their implementation decreases in ten times [20]. The goal is to directly replace animal testing with non-animal methods. Advances in cell and molecular biology and informatics need to be leveraged to develop new specific preclinical testing strategies that are applicable to specific human situations [21].

This work aims to evaluate the biological activity of chemical peeling substances using enzymatic and Arrhenius kinetics for a single-cell model Spirostomum ambiguum as an alternative approach to animal experiments.

\section{MATERIALS AND METHODS}

\section{Cell model}

The test culture Spirostomum ambiguum (Sp. ambiguum) has been cultured in the laboratory to carry out studies of individual and combined biological activity of medicines.

The protozoan ciliate $S p$. ambiguum is characterized by tape-shaped, dorsal body shape (1-3 mm long), has a macronucleus clear-shaped and mouth apparatus up to the back third of the body (fig. 1).

Compared to other objects of biological testing, Sp. ambiguum have several advantages, since they are eukaryotic organisms. The statistically reliable sensitivity to toxicants makes it possible to compare the response of protozoa with that of humans [23, 24].

Under favorable conditions in a low-mineralized environment, cells do not die for a period exceeding their cell cycle (about $20 \mathrm{~h}$ ).

When incubated into a toxicant solution, cells die over time, which is a function of both concentration and temperature. Kinetic scheme of ligand-induced death of $S p$. ambiguum includes the reversible reaction with the formation of an intermediate product $\left(C \bullet \mathrm{L}_{n}\right)$ and the state of transition to cell death (DC) (fig. 2). 


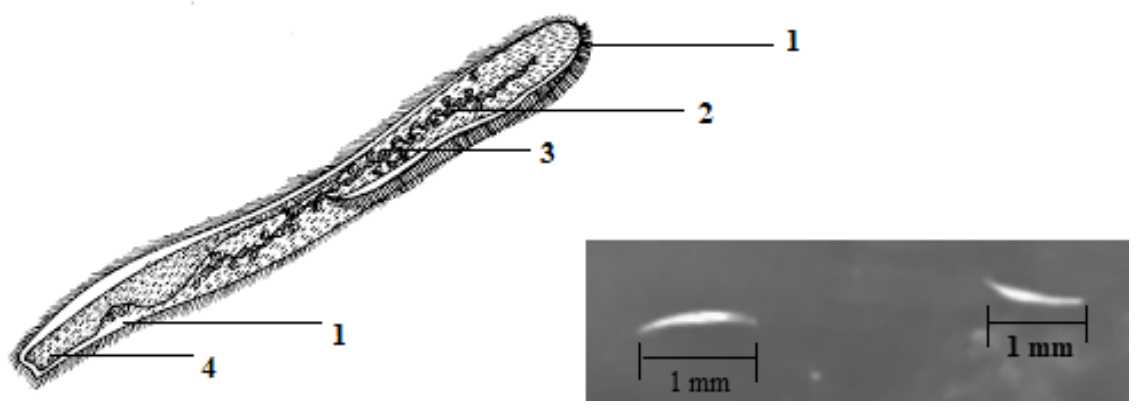

Fig. 1: The general features of Sp. ambiguum ciliates: 1-peristom; 2-large macronucleus; 3-small micronuclei; 4-reducing vacuole; in the insert-a light microscope image of Spirostomum ambiguum in real laboratory settings [22]

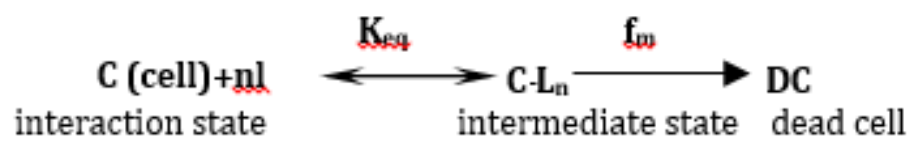

Fig. 2: Kinetic scheme of ligand-receptor interaction Sp. ambiguum with xenobiotic (L) [25]

The presence of an intermediate state of ligand-induced death means that the process of cell death should be activated and proceeds with energy consumption [26, 27]. Indeed, we have established the dependence of $S$. ambiguum mortality on temperature using the models of pharmaceutical substances for chemical peeling.

\section{Powder substance samples}

1. Glycolic acid $\left(\mathrm{HOCH}_{2} \mathrm{COOH}\right), 2$-Hydroxyacetic Acid (fig. 3) colorless hygroscopic crystals, that soften, separate, and cause desquamation of the cornified epithelium or horny layer of skin (ReagentPlus®, 99\% Sigma-Aldrich) [28].<smiles>O=C(O)CO</smiles>

\section{2-Hydroxyethanoic acid}

Fig. 3: Chemical structure of glycolic acid

2. Carbolic acid $\left(\mathrm{C}_{6} \mathrm{H}_{6} \mathrm{O}\right)$ also known as phenol, hydroxybenzene (fig. 4). It is also used as an antiseptic and disinfectant (chemical that kills bacteria and fungi) and in medicinal preparations such as mouthwash and sore throat lozenges (BioUltra, for molecular biology, $\geq 99.5 \%$ Sigma-Aldrich).<smiles>Oc1ccccc1</smiles>

Benzenol

Fig. 4: Chemical structure of carbolic acid

\section{Technique of research}

The installation of the Spirotox method includes the following blocks: a glass thermostatic cell with five recesses for solutions; Lauda AlphaA 6 thermostat; Binoculars IBS-10; Daylight lamp (10 W) for field observations. The analyzed sample aliquot and 3-5 test culture individuals were introduced into the thermostatic cell holes $(\mathrm{V}=150 \mu \mathrm{l})$. The pipette with a diameter of more than $1 \mathrm{~mm}$ was used to avoid infusoria injuries. The death of the cell was stated by the rupture of the membrane with the release of the contents of the protoplasm outwards or by immobilization with no contractile reaction to mechanical irritation.

\section{Statistics}

The findings were processed by the statistical methods using software packages of Origin Pro 9.1. Each value on the fig. represents as average mean $\pm S D$; $p$ values less than 0.001 were considered as significant.

\section{RESULTS AND DISCUSSION}

Determination of chemical peelings solution toxic concentration

To study the biological activity of glycolic acid on the cell model the range of six concentrations values from 4.5 to $12.0 \mathrm{mmol} \cdot \mathrm{l}^{-1}$ was chosen to visually monitor the behavior of ciliates. For carbolic acid solutions, the test range of concentrations ranged from 2.0 to $6.1 \mathrm{mmol} \cdot \mathrm{l}^{-1}$ (fig. 5). The graphs in semilogarithmic coordinates made it possible to determine the boundary values of the concentration of the cell transition from the intermediate state $C \cdot L_{n}$ to the dead state DC. The intermediate state is characterized by a change in the morphometric characteristics of cells, the appearance of cytoplasmic grains and a decrease in the intensity of movement. The rupture of the cell membrane and the release of endoplasm into the external environment were accompanied by cell death at a concentration of glycolic acid solutions above 5.3 $\mathrm{mmol} \cdot \mathrm{l}^{-1}$ and carbolic acid above $2.8 \mathrm{mmol} \cdot \mathrm{l}^{-1}$.

\section{Determination of the affinity for the cell receptor degree}

Using the idea of a living cell as a multi-fermented multiphase chemical reactor [29-31] allows to describe the interaction of $S p$. ambiguum receptors with chemical peels substances by the Hill equation (at $\mathrm{n}=1$ we obtain the Michaelis-Menten equation):

$$
{ }^{\circ{ }^{\circ} f_{m}}=\mathrm{f}_{m}\left(1+\mathrm{K}_{e q} /[\mathrm{L}]^{n}\right)
$$

The expression for Sp. ambiguum lifetime $\left(t_{L}\right)$ can be written in the form [32-34]:

$$
t_{\mathrm{L}}=1 / \mathrm{f}_{m}+\mathrm{K}_{e q} / \mathrm{f}_{m} \times 1 /[\mathrm{L}]^{n},
$$

Where ${ }^{\circ b} f_{m}$ is the observed rate constant of the cell transition to the dead state (cell death rate), $K_{\text {eq }}$ represents the equilibrium constant, [L] is the xenobiotic concentration and $n$-stoichiometric coefficient in kinetic scheme (fig. 2).

The straight line of the dependence $t_{L}=F\left(1 /[L]^{n}\right)$ makes it possible to determine the values of the death rate $f_{m}=1 / \mathrm{t}_{\mathrm{L}}$ at the ordinate intersection and the equilibrium constant of the formation of the intermediate complex $K_{e q}$ at the abscissa intersection with an appropriate choice of stoichiometric coefficient $n$ [32-36]. Calculations have shown that for glycolic acid $n=2$ and for carbolic acid $n=3$. The linearization of the experimental results in the indicated coordinates at other values is less reliable (fig. 6 , table 1 ). Thus, the using kinetic model describes the mechanisms of ligandreceptor interaction of the xenobiotics with the living cell. 

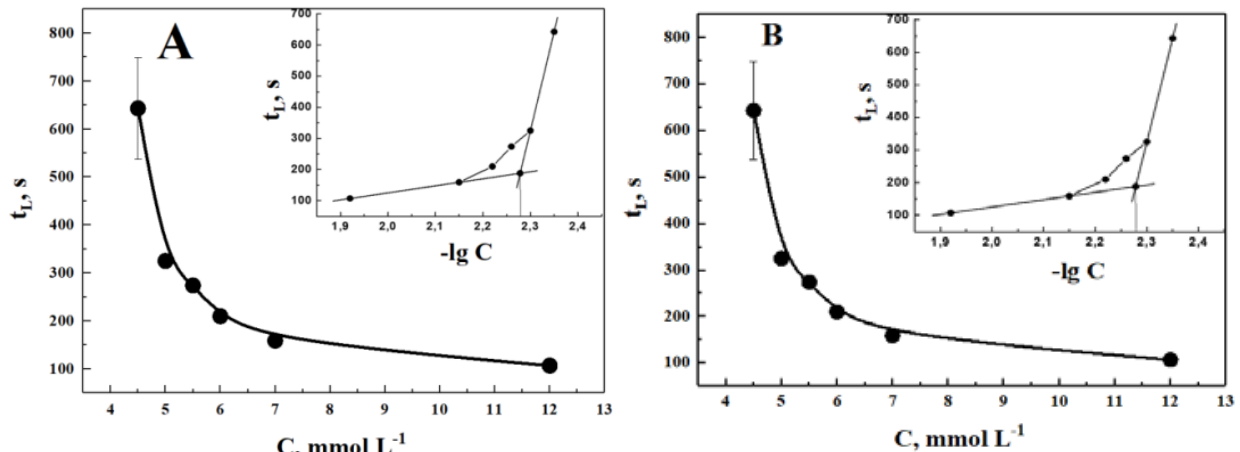

Fig. 5: Dependence of cellular biosensor lifetime on the concentration of water solutions of glycolic (A) and carbolic (B) acids; $n=5$; $p<0.001$. The inset shows the dependence $t_{L}=f(\operatorname{lgC})$
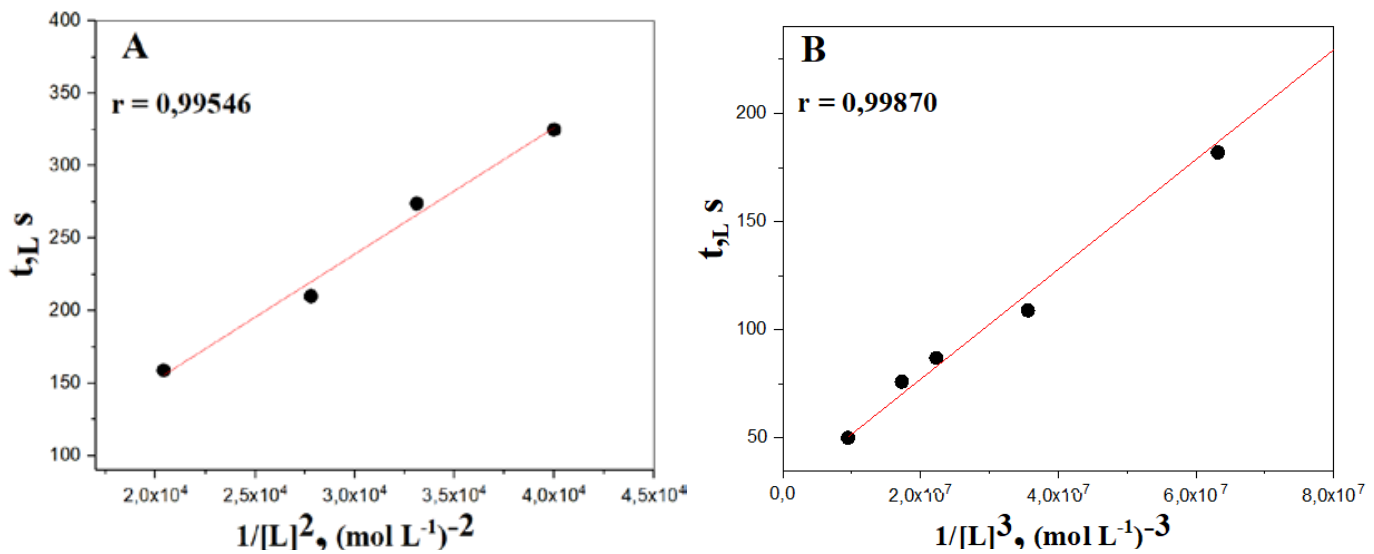

Fig. 6: Relationship of the lifetime of Sp. ambiguum as a function of the concentration of glycolic (A) and carbolic (B) acids

Table 1: Kinetic parameters of ligand-receptor interactions of the chemical peeling agents and $S p$. ambiguum (n= 5; p<0.001)

\begin{tabular}{lllll}
\hline $\begin{array}{l}\text { Chemical peeling } \\
\text { agent }\end{array}$ & $\begin{array}{l}\text { Toxic concentration, } \\
\boldsymbol{C}, \mathbf{~ m m o l} \cdot \mathbf{l}^{-\mathbf{1}}\end{array}$ & $\begin{array}{l}\text { Stoichiometric } \\
\text { coefficient, } \boldsymbol{n}\end{array}$ & $\begin{array}{l}\text { Equilibrium constant of } \\
\text { intermediate state, } \boldsymbol{K}_{\boldsymbol{e q}}\end{array}$ & $\begin{array}{l}\text { The rate constant of a cell } \\
\text { transition to the DC state, } \boldsymbol{f}_{\mathbf{m}}, \mathbf{s}^{\mathbf{- 1}}\end{array}$ \\
\hline $\begin{array}{l}\text { Glycolic acid } \\
\text { Carbolic acid }\end{array}$ & 5.3 & 2 & $7.50 \cdot 10^{-5}$ & $9.40 \cdot 10^{-3}$ \\
& 2.8 & 3 & $1.14 \cdot 10^{-7}$ & $4.42 \cdot 10^{-2}$ \\
\hline
\end{tabular}

The $K_{e q}$ and $f_{m}$ values reflecting the mechanism of the toxic effect of aqueous solutions for chemical peeling at the stage of the formation of the intermediate complex and the reaction product are analogous to the Michaelis-Menten constant $\left(\mathrm{K}_{\mathrm{m}}\right)$ and $\mathrm{V}_{\max }$ at $n=1$.

Thus, the efficiency of the ligand-receptor interaction in the "chemical peeling agent-living cell" system can be assessed using the
Spirotox eukaryotic cell model. Low values of the equilibrium constant $K_{e q}$ for the formation of the intermediate product $\mathrm{C} \cdot \mathrm{L}_{\mathrm{n}}$, as well as high values of the rate $f_{m}$ of the cell's transition to the lethal state with an increase in the number of attached ligands $n$, indicate a high biological activity of the xenobiotic. This is clearly demonstrated by both glycolic and carbolic acids and by other xenobiotics studied earlier $[37,38]$.

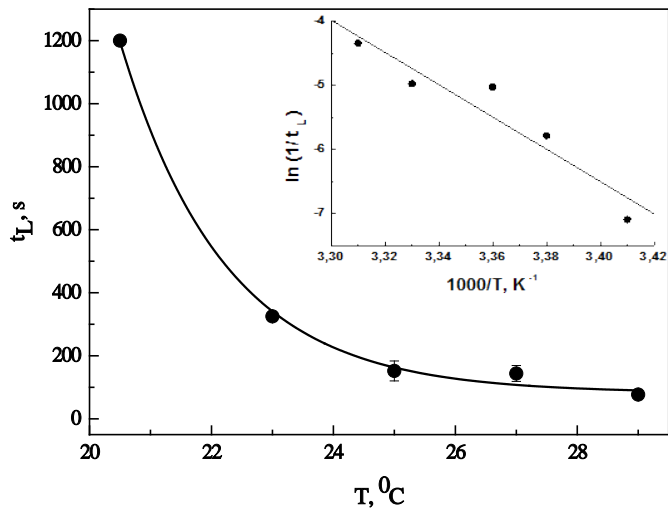

A

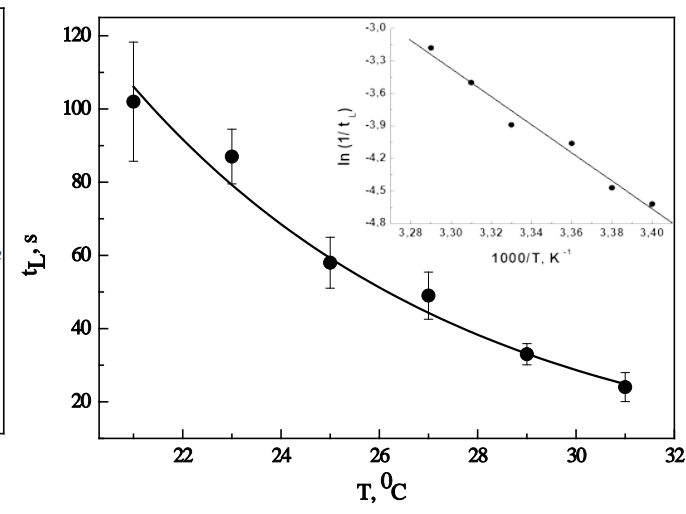

B

Fig. 7: Relationship of the lifetime of Sp. ambiguum as a function of temperature in direct and Arrhenius coordinates at infusoria incubation in solutions of glycolic ( $\left.5 \mathrm{mmol} \cdot \mathrm{l}^{-1}\right)-A$ and carbolic $\left(3 \mathrm{mmol} \cdot \mathrm{l}^{-1}\right)-\mathrm{B}$ acids; $\mathrm{n}=5 ; \mathrm{p}<0.001$ 
Temperature dependence of the rate of Sp. ambiguum death in solutions of peeling acids

The presence of an intermediate state $\mathrm{C} \bullet \mathrm{Ln}$ in the process of ligandinduced death of the test object means that the process of cell death must occur with the consumption of energy. Using the examples of xenobiotics of different natures, we found that ligand-induced cellular transformations are linearized in Arrenius coordinates:

$$
\ln \mathrm{k}=\ln \mathrm{A}-\frac{\mathrm{E}_{\mathrm{a}}}{\mathrm{R}} \cdot \frac{1}{\mathrm{~T}} \ldots
$$

here $k$ is the rate constant, $A$ is the pre-exponential factor, $E_{a}$ is the activation energy $\left(\mathrm{J} \cdot \mathrm{mol}^{-1}\right), R$ is the ideal gas constant $\left(8.314 \mathrm{~J} \cdot \mathrm{mol}^{-}\right.$ ${ }^{1} \cdot \mathrm{K}^{-1}$ ), and $T$ is the absolute temperature.

In semilogarithmic coordinates, the tangent of the straight line slope $\ln \left(1 / t_{\mathrm{L}}\right)=\mathrm{F}(1 / \mathrm{T})$ to the abscissa axis is $\mathrm{E}_{\mathrm{a}} / \mathrm{R}$ (fig. 7) $[39,40]$.

The values of observed activation energy ( ${ }^{\circ b} \mathrm{Ea}$ ) for the test compounds have been found, using Arrhenius coordinates (table 2).

Table 2: The calculated ${ }^{\circ b s}$ Ea values of ligand-induced $S$. ambiguum death process in water solutions of the chemical peeling agents; $n=5 ; p<0.001$

\begin{tabular}{ll}
\hline Chemical peeling agent & ${ }^{\text {obsEa }} \mathbf{S D}, \mathbf{~ k J} \cdot \mathbf{m o l}^{-\mathbf{1}}$ \\
\hline Glycolic acid & $210 \pm 0.39$ \\
Carbolic acid & $108 \pm 0.09$ \\
\hline
\end{tabular}

The lower activation energy, as well as the reduction of $S p$. ambiguum lifetime by about ten times at the same temperature for carbolic acid compared to glycolic acid, indicates higher biological activity of this pilling agent. According to our data, substances with high biological activity, characterized by low cell survival, correspond to low ${ }^{\circ b s}$ Ea values, which are consistent with the values toxicity for organisms of a higher hierarchical level (fig. 8).

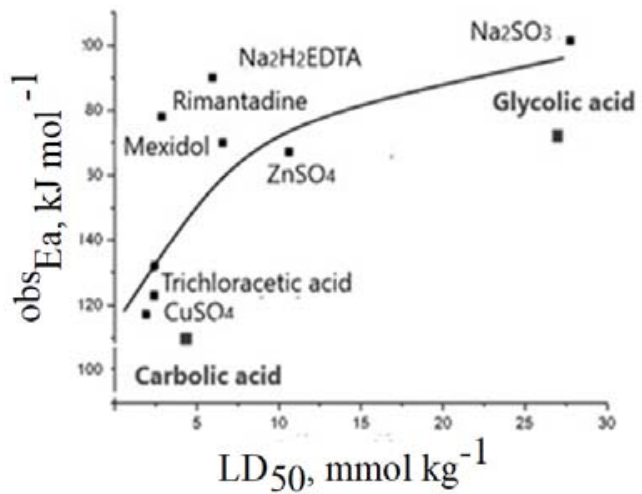

Fig. 8: Dependence of the ${ }^{o b s} E_{a}$ of $S p$. ambiguum mortality on average lethal doses of $L D_{50}\left(\mathrm{mmol} \cdot \mathrm{kg}^{-1}\right.$, rats, per os) for different pharmaceutical substances

As would be expected, there is a high correlation between the values of the apparent activation energy and $\mathrm{LD}_{50}$ (rats, per os) of chemical peeling substances and other pharmaceuticals [41].

\section{CONCLUSION}

Animal experiments can predict the effectiveness and safety of drugs in humans. Millions of mice, rats, hamsters, guinea pigs, rabbits, cats, dogs, monkeys and chickens are used for research, educational, and industrial purposes. Ethical issues with the use of experimental animals are the result of a conflict between the importance of animal experimentation to basic science and ethical principles that prevent actions from causing pain and suffering. The article presents the results of studies that exclude ethical conflicts. The efficiency of the ligand-receptor interaction in the "chemical peeling agent-living cell" system was assessed using the Sp. ambiguum model of eukaryotic cells. The Spirotox method was based on the MichaelisMenten enzymatic kinetics and the temperature dependence of the Arrhenius reaction rate. Low values of the equilibrium constant $K_{e q}$ for the formation of the intermediate product $C \cdot L_{n}$, high values of the rate $f_{m}$ of cell transition to the lethal state and the degree of cooperativity $n$ indicate a high biological activity of the xenobiotic. The correlation between the values of activation energies ${ }^{{ }^{b} s} E_{a}$ and $D L_{50}$ of mammals was proved.

The developed physicochemical and biological models can be used for any peeling substances.

\section{ACKNOWLEDGEMENT}

We are grateful to the RUDN Medical Institute for support in research.

\section{FUNDING}

This paper has been supported by the RUDN University Strategic Academic Leadership Program

\section{AUTHORS CONTRIBUTIONS}

PTV developed the concept of the study. UEV designed the study and guided and supervised the study. PTV and UEV contributed to the interpretation of data and wrote the first draft. PMH and KIV was associated in supervising, advising and positioning the manuscript. All authors read and made corrections to the finalized manuscript before submission.

\section{CONFLICTS OF INTERESTS}

The authors declare that there is no conflict of interests.

\section{REFERENCES}

1. Gowrisankar L, Ganesh Murali J, Usha P. Natural biomaterials for skin tissue engineering: repair and regeneration-a short review. Asian J Pharm Clin Res 2018;11:16-20.

2. Kim SJ, Baek JH, Koh JS, Bae MI, Lee SJ, Shin MK. The effect of physically applied alpha hydroxyl acids on the skin pore and comedone. Int J Cosmet Sci 2015;37:519-25.

3. El Samahy M, Ghoz M, Ramzy N. Morphological investigation of chemical peel on photodamaged facial skin. Int J Cosmet Sci 1998;20:269-82.

4. Velasco MVR, Vieira RP, Fernandes AR. Short term clinical of peel off facial mask moisturizers. Int J Cosmet Sci 2014;36:355-60.

5. Lee KC, Wambier CG, Soon SL. Basic chemical peeling: superficial and medium-depth peels. J Am Acad Dermatol 2019;81:313-24.

6. Ursin F, Steger F, Borelli C. Katharsis of the skin: peeling applications and agents of chemical peelings in Greek medical textbooks of graeco-roman antiquity. J Eur Acad Dermatol Venereol 2018;32:2034-40.

7. Balakrishnan J, JR Appalasamy. Skin infection and the global challenges: a review. An Bras Dermatol 2017;92:212-6.

8. Soleymani T, Lanoue J, Rahman Z. A practical approach to chemical peels: a review of fundamentals and step-by-step algorithmic protocol for treatment. Int J Pharm Sci 2016;8:1-3.

9. Busquet F, Hartung T, Pallocca G. Harnessing the power of novel animal free test methods for the development of COVID 19 drugs and vaccines. Arch Toxicol 2020;94:2263-72.

10. Anuradha SN, Vilashene AP, Ganasan Lalithambigai AP, Joobi SA. Cosmeceuticals: an opinion in the direction of pharmaceuticals. Asian J Pharm Clin Res 2015;8:64-9.

11. Hartung T. E-Cigarettes and the need and opportunities for alternatives to animal testing. Altex 2016;33:211-24.

12. Busquet F, Kleensang A, Rovida C, Herrmann K, Leist M, Hartung T. New European Union statistics on laboratory animal use-what really counts. ALTEX 2020;37:167-86.

13. Flecknell P. Replacement, reduction and refinement. ALTEX 2002;19:73-8.

14. Tannenbaum J, Bennett BT. Russell and Burch's 3Rs then and now: the need for clarity in definition and purpose. J Am Assoc Lab Anim Sci 2015;54:120-32.

15. Pan-on S, Rujivipat S, Ounaroon A, Kongkaew C, Tiyaboonchai W. Development, characterization and skin irritation of 
mangosteen peel extract solid dispersion containing clay facial mask. Int J Appl Pharm 2018;10:202-8.

16. Liu Z, Huang R, Roberts R, Tong W. Toxicogenomics: a 2020 vision. Trends Pharmacol Sci 2019;40:92-103.

17. Hartung T. Perspectives on in vitro to in vivo extrapolations. Appl In Vitro Toxicol 2018;4:305-16.

18. Yamamoto Y, Wanibuchi S, Sato A, Kasahara T, Fujita M Precipitation of test chemicals in reaction solutions used in the amino acid derivative reactivity assay and the direct peptide reactivity assay. J Pharmacol Toxicol Methods 2019;100. DOI:10.1016/j.vascn.2019.106624

19. Emanuel NM. Kinetics and free-radical mechanisms of ageing and carcinogenesis. IARC Sci Publ 1985;58:127-50.

20. Lang BF, O'Kelly C, Nerad T, Gray MW, Burger G. The closest unicellular relatives of animals. Curr Biol 2002;12:1773-8.

21. Balls M. It's time to reconsider the principles of humane experimental technique. Altern Lab Anim 2020;48:40-6.

22. Xu LX, Bhamla MS. Biophysical mechanism of ultrafast helical twisting contraction in the giant unicellular ciliate spirostomum ambiguum. bioRxiv 2019;25:1-10.

23. Mahavir J, Sneh L, Preeti K, Tulika M. Application of nanostructures in antimicrobial therapy, Int J Appl Pharm 2018;10:11-5.

24. Stom DI, Bybin VA, Balayan AE, Saksonov MN, Salovarova VP. The influence of pharmaceutical vermipreparations on the testreaction of organisms of the different levels of the organization. Pharmacogn Res 2014;6:195-8.

25. Goncharuk VV, Syroeshkin AV, Zlatskiy IA, Uspenskaya EV, Orekhova AV, Levitskaya OV, et al. Quasichemical description of the cell death kinetics of cellular biosensor Spirostomum ambigua for testing the biological activity of aqueous solutions. J Water Chem Tech 2017;39:97-102.

26. Syroeshkin A, Uspenskaya E, Pleteneva T, Morozova M, Maksimova T, Koldina A, et al. Mechanochemical activation of pharmaceutical substances as a factor for modification of their physical, chemical and biological properties. Int J Appl Pharm 2019;11:118-23.

27. Levitskaya OV, Syroeshkin AV, Pleteneva TV. Arrhenius kinetics as a bioactivity assessment criterion for drug substances and excipients. Pharm Chem J 2016;49:779-81.

28. Bello YD, Hisadora FP, Farina AP. Glycolic acid as the final irrigant in endodontics: mechanical and cytotoxic effects. Mater Sci Eng C 2019;100:323-9.

29. Simon AJ, Vallee Bélisle A, Ricci F, Watkins HM, Plaxco KW Using the population-shift mechanism to rationally introduce
"Hill-type" cooperativity into a normally non-cooperative receptor. Angew Chem Int Ed 2014;53:9471-5.

30. Patiha, Heraldy E, Hidayat Y, Firdaus M. The langmuir isotherm adsorption equation: the monolayer approach. IOP Conf Ser: Mater Sci Eng 2016;107:012067.

31. Hofmeyr JH, Cornish Bowden A. The reversible Hill equation: how to incorporate cooperative enzymes into metabolic models. Comput Appl Biosci 1997;13:377-85.

32. Nimibofa A, Newton Augustus E, Donbebe W. Modelling and interpretation of adsorption isotherms. J Chem 2017;11. https://doi.org/10.1155/2017/3039817

33. Uspenskaya EV, Pleteneva TV, Syroeshkin AV, Taravrina IV. Preparation, characterization and studies of physicochemical and biological properties of drugs coating lactose in fluidized beds. Int J Appl Pharm 2020;12:272-8.

34. Fisher R. Significance of the michaelis constant. Nature 1963;197:799.

35. Burns RA Jr, El-Sayed MY, Roberts MF. Kinetic model for surface-active enzymes based on the Langmuir adsorption isotherm: phospholipase $\mathrm{C}$ (Bacillus cereus) activity toward dimyristoyl phosphatidylcholine/detergent micelles. Proc Natl Acad Sci USA 1982;79:4902-6.

36. Hamzaoui M, Bestani B, Benderdouche N. The use of linear and nonlinear methods for adsorption isotherm optimization of basic green 4-dye onto sawdust-based activated carbon. J Mater Environ Sci 2018;9:1110-8.

37. Gross BG. Cardiac arrhythmias during phenol face peeling. Plast Reconstr Surg 1984;7:590-4.

38. Peric S, Bubanj M, Bubanj S, Jancic S. Side effects assessment in glicolyc acid peelings in patients with acne type I. Bosn J Basic Med Sci 2011;11:52-7.

39. Oliveira AHD, RDS Leite, FH Dantas, VGD Souza, JVC Junior, F SD Souza, et al. Thermal degradation kinetics of kaempferol and quercetin in the pre-formulated of the standardized extracts of poincianella pyramidalis (tul.) l. p. queiroz obtained by spray dryer. Int J Pharm Sci 2017;9:123-8.

40. Anuhya G, Jyostna V, Aswani Kumar YVV, Bodaiah B, Sudhakar $P$. Influence of physico-chemical parameters on secondary metabolite production by marine fungi. Int J Curr Pharm Res 2017;9:112-8.

41. Çelik I. Determination of toxicity of trichloroacetic acid in rats: $50 \mathrm{~d}$ drinking water study. Pestic Biochem Physiol 2007;89:39-45 